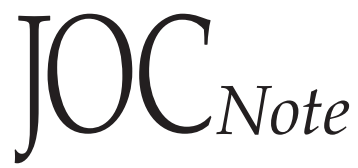

\section{Facile Synthesis of Saponins Containing 2,3-Branched Oligosaccharides by Using Partially Protected Glycosyl Donors}

\author{
Guofeng Gu, ${ }^{\dagger}$ Yuguo Du, ${ }^{*}{ }^{\dagger}$ and Robert J . Linhardt*,‡ \\ Research Center for Eco-Environmental Sciences, \\ Chinese Academy of Sciences, Beijing 100085, China, and \\ Departments of Chemistry and Chemical Biology, Biology, \\ and Chemical and Biological Engineering, Rensselaer \\ Polytechnic Institute, Troy, New York 12180
}

\section{duyuguo@mail.rcees.ac.cn}

Received April 12, 2004

\begin{abstract}
Two natural saponins $\mathbf{1}$ and 2, isolated from Solanum indicum L., and containing 2,3-branched sugar moieties, have been efficiently synthesized. Partially protected monosaccharide and disaccharide donors were used to facilitate target synthesis. Stereo factors were critical in incorporating 2,3-branched sugars on steroid aglycones. Saponin 1 was synthesized in five steps and 30\% overall yield, while saponin $\mathbf{2}$ was obtained using six straightforward sequential reactions in 31\% overall yield. Saponin 2 shows promising cytotoxic activity toward human hepatocellular carcinoma BEL-7402 with an $\mathrm{IC}_{50}$ of $<6 \mu \mathrm{g} / \mathrm{mL}$.
\end{abstract}

Saponins constitute a structurally and biologically diverse class of molecules that are widely distributed in terrestrial plants and in certain marine organisms. ${ }^{1}$ Most traditional Chinese medicines contain saponins as major components and, thus, represent glycoconjugate templates in drug design and devel opment. ${ }^{2}$ Dioscin (diosgenyl 2,4-di-O- $\alpha$-L-rhamnopyranosyl- $\beta$-D-glucopyranoside), $\mathrm{Pa}$ (diosgenyl $\alpha$-L-rhamnopyranosyl-( $1 \rightarrow 2)$-[ $\alpha$-L-arabinofuranosyl-(1 $\rightarrow 4)$ ]- $\beta$-D-glucopyranoside), methyl protodioscin (3-O-(2,4-di-O- $\alpha$-L-rhamnopyranosyl- $\beta$-D-glucopyranosyl)-26-O-( $\beta$-D-glucopyranosyl )-22-methoxy-25(R)furost-5-ene-3 $\beta, 26$-diol), and balanitin 7 (diosgenyl $\alpha$-Lrhamnopyranosyl-( $1 \rightarrow 2)$ - $[\beta$-D-xyl opyranosyl-( $(\rightarrow 3)-\beta$-Dglucopyranosyl-(1 $\rightarrow 4$ ]- $\beta$-D-glucopyranoside) are all clinically recognized for their cardiovascular, antifungal, and antitumor activities. ${ }^{3}$ Both the carbohydrate and steroid

${ }^{\dagger}$ Chinese Academy of Sciences.

‡ Rensselaer Polytechnic Institute.

(1) (a) Hostettmann, K.; Marston, A. Saponins; Cambridge University Press: 1995. (b) Iorizzi, M.; De Marino, S.; Zollo, F. Curr. Org. Chem. 2001, 5, 951.

(2) (a) Guo, C.; Fuchs, P. L. Tetrahedron Lett. 1998, 39, 1099. (b) Deng, S.; Yu, B.; Lou, Y.; Hui, Y. J . Org. Chem. 1999, 64, 202. (c) Deng, S.; Yu, B.; Hui, Y. Tetrahedron Lett. 1998, 39, 6511. (d) Yu, B.; Xie, J .; Deng, S.; Hui, Y.J. . Am. Chem. Soc. 1999, 121, 12196. (e) Yu, W.; J in, Z. J . Am. Chem. Soc. 2001, 123, 3369. (f) Yu, W.; J in, Z. J . Am. Chem. Soc. 2002, 124, 6576. (g) Cheng, M. S.; Wang, Q. L.; Tian, Q.; Song, H. Y.; Liu, Y. X.; Li, Q.; Xu, X.; Miao, H. D.; Yao, X. S.; Yang, Z. J . Org. Chem. 2003, 68, 3658.

(3) (a) Nakano, K.; Murakami, K.; Takaishi, Y.; Tomimatsu, T.; Nohara, T. Chem. Pharm. Bull. 1989, 37, 116. (b) Hufford, C. D.; Liu, S.; Clark, A. M. J . Nat. Prod. 1988, 51, 94. (c) Liu, C.; Chen, Y. Acta Pharm. Sinica 1984, 19, 799. (d) Namba, T.; Huang, X.; Shu, Y.; Huang, S.; Hattoti, M.; Kakiuchi, N.; Wang, Q.; Xu, G. Planta Med. 1989, 55, 501. (e) Zhou, J. Pure Appl. Chem. 1989, 61, 457. (f) Hu, K.; Dong, A J .; Yao, X. S.; Kobayashi, H.; I wasaki, S. Planta Med. 1997, 63, 161. (g) Nohara, T.; Yabuta, H.; Suenobu, M.; Hida, R.; Miyahara, K.; Kawasaki, T. Chem. Pharm. Bull. 1973, 21, 1240. components of saponins are structurally essential for their bioactivities. ${ }^{4}$ F or example, removal of ester-linked tetrasaccharide from julibroside, a bioactive saponin isolated from Albizia julibrissin, dramatically decreases its cytotoxicity against KB cells, ${ }^{5}$ and the rhamnose moiety of solamargine (solasodinyl 2,4-di-O- $\alpha$-L-rhamnopyranosyl- $\beta$-D-glucopyranoside) plays a crucial role in triggering cell death by apoptosis. ${ }^{6}$ The great difficulty associated with purification of closely related saponins from natural sources makes chemical synthesis the most realistic approach for obtaining homogeneous saponins. Significant effort has been directed toward the development of novel, powerful glycosylation reactions or strategies to access defined glycoconjugates. ${ }^{7}$ Natural saponins containing 2,3-branched carbohydrate moieties are typically assembled in two ways. The first strategy is to couple a 4,6-benzylidenated reducing end sugar unit to $\mathrm{C}-3$ of the steroid or triterpene aglycone. Protection group manipulation (2-OH/3-OH), followed by glycosylation (3$\mathrm{OH} / 2-\mathrm{OH})$, deprotection (2-OH/3-OH), and a second glycosylation $(2-\mathrm{OH} / 3-\mathrm{OH})$, furnishes the natural saponin having a 2,3-dibranched sugar structure. ${ }^{8}$ The disadvantages of this strategy are that it is a lengthy and lowefficiency synthesis. More importantly, it is sometimes problematic to remove the 2-acyl protecting group prior to a second glycosylation step. ${ }^{9}$ In the second strategy, a 2,3-branched oligosaccharide is first prepared and used to glycosylate the aglycone in the final step. Unfortunately, the final glycosylation step often affords an $\alpha, \beta$ mixture due to the absence of C-2 neighboring group participation. ${ }^{10,5 b}$ We recently described a new strategy for preparing natural saponins having 2,4-branched ol igosaccharides that relies on partially protected glycosyl donors. ${ }^{11}$ We report here the extension of this strategy to the facile synthesis of natural saponins containing 2,3branched oligosaccharides, diosgenyl 3-O-\{ $\alpha$-L-rhamnopyranosyl-( $1 \rightarrow 2)$-[ $\beta$-D-glucopyranosyl-( $1 \rightarrow 3)]-\beta$-D-galactopyranoside\} (1) and diosgenyl 3-O-\{ $\alpha-L-$ rhamnopyranosyl$(1 \rightarrow 2)$-[ $\beta$-D-xyl opyranosyl-( $1 \rightarrow 3)]-\beta$-D-galactopyranoside\} (2). These saponins had previously been extracted from Solanum indicum L., ${ }^{12}$ a traditional Chinese medicinal plant that has long been used for its antiinflam-

(4) Matsuda, H.; Pongpiriyadacha, Y.; Morikawa, T.; Kishi, A.; Kataoka, K.; Yoshikawa, M. Bioorg. Med. Chem. Lett. 2003, 13, 1101.

(5) (a) I keda, T.; Fujiwara, S.; Araki, K.; Kinjo, J .; Nohara, T.; Miyoshi, T. J. Nat. Prod. 1997, 60, 102. (b) I keda, T.; Kajimoto, T. Kinjo, J .; Nakayama, K.; Nohara, T. Tetrahedron Lett. 1998, 39, 3513. (c) Du, Y.; Zhang, M.; Kong, F. J. Chem. Soc., Perkin Trans. 1 2001, 2289.

(6) Chang, L.-C.; Tsai, T.-R.; Wang, J .-J .; Lin, C.-N.; Kuo, K.-W. Biochem. Biophys. Res. Commun. 1998, 242, 21.

(7) For reviews see: (a) Toshima, K.; Tasuta, K. Chem. Rev. 1993 93, 1503. (b) Schmidt, R. R.; Kinzy, W. Adv. Carbohydr. Chem. Biochem. 1994, 50, 21. (c) Garegg, P. J. Adv. Carbohydr. Chem. Biochem. 1997, 52, 179.

(8) Li, C.; Yu, B.; Liu, M.; Hui, Y. Carbohydr. Res. 1998, 306, 189.

(9) (a) Deng, S.; Yu, B.; Hui, Y.; Yu, B.; Han, X. Carbohydr. Res. 1999, 317, 53. (b) Suhr, R.; Pfefferkorn, P.; Weingarten, S.; Thiem, J Org. Biomol. Chem. 2003, 1, 4373.

(10) (a) Liu, M.; Yu, B.; Hui, Y. Tetrahedron Lett. 1998, 39, 415. (b) Ikeda, T.; Miyashita, H.; Kajimoto, T.; Nohara, T. Tetrahedron Lett. 2001, 42, 2353.

(11) Du, Y.; Gu, G.; Wei, G.; Hua, Y.; Linhardt, R. J . Org. Lett. 2003 5, 3627 


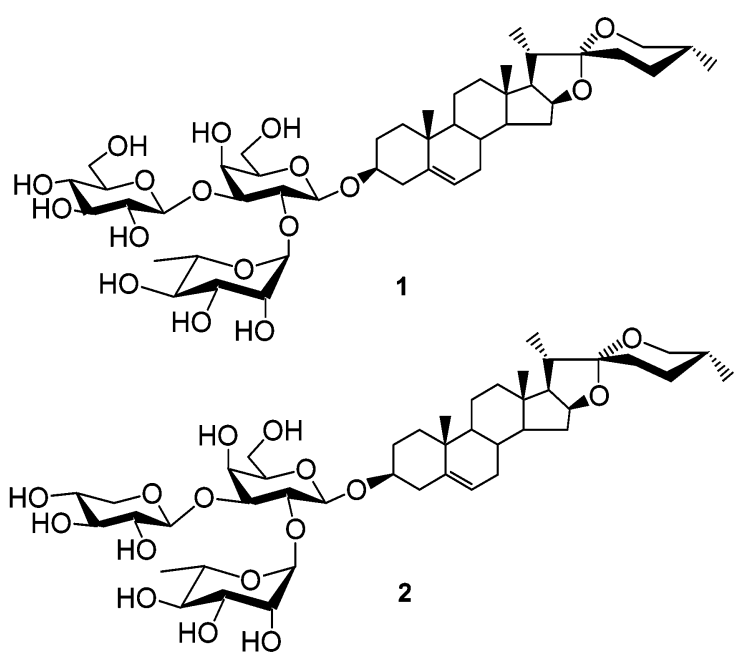

FIGURE 1. Structure of saponin target compounds $\mathbf{1}$ and $\mathbf{2}$.

SCHEME 1. Attempted Synthesis of Saponin $1^{\mathrm{a}}$

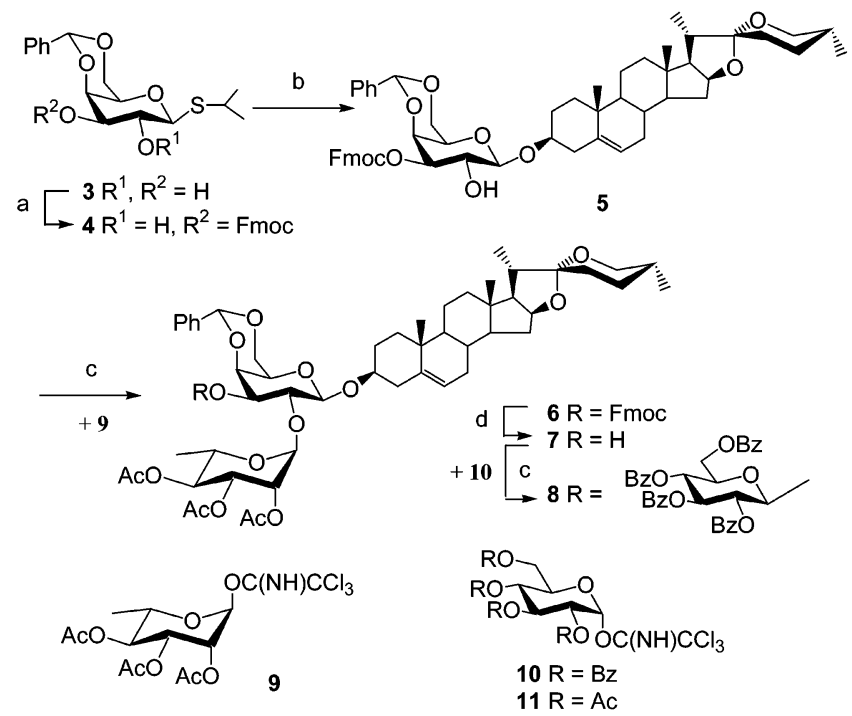

a Reagents and conditions: (a) $\mathrm{FmocCl}, \mathrm{Pyr}, \mathrm{DMAP}, 0{ }^{\circ} \mathrm{C}$ to room temperature, $87 \%$. (b) Diosgenin, NIS, TMSOTf, $\mathrm{CH}_{2} \mathrm{Cl}_{2},-42$ ${ }^{\circ} \mathrm{C}, 75 \%$. (c) TMSOTf, $\mathrm{CH}_{2} \mathrm{Cl}_{2}, 0{ }^{\circ} \mathrm{C}, 88 \%$ for $\mathbf{6} ; 27 \%$ for 8. (d) $\mathrm{Et}_{3} \mathrm{~N}$, $85 \%$ from 5 .

matory activity.In our previous study, ${ }_{11}^{11}$ we showed that direct coupling of isopropyl 4,6-O-benzylidene-1-thio- $\beta$ D-gal actopyranosi de (3) with di osgenin gave complicated mixtures. Thus, in our first attempt to synthesize $\mathbf{1}$, the 3-OH of $\mathbf{3}$ was regioselectively protected by 9 -fluorenylmethyloxycarbonyl ( $\mathrm{Fmoc}$ ) using $\mathrm{FmocCl}$ in pyridine, yiel ding partially protected donor $\mathbf{4},{ }^{13}$ which was used to glycosylate diosgenin affording saponin derivative $\mathbf{5}$ (Scheme 1) in 75\% yield. Glycosylation of $\mathbf{5}$ with rhamnosyl imidate 9 gave di saccharide glycoside $\mathbf{6}$, and $\mathrm{Et}_{3} \mathrm{~N}$ promoted removal of $\mathrm{Fmoc}$ furnished acceptor $\mathbf{7}$ in onepot (85\% for two steps). In this straightforward strategy, the final glycosylation of saponin derivative $\mathbf{7}$ with

(12) (a) Yahara, S.; Nakamura, T.; Someya, Y.; Matsumoto, T.; Yamashita, T.; Nohara, T. Phytochemistry 1996, 43, 1319. (b) Chen, P.; Zheng, G. Chinese Herbs and Compatibility; Science PressOhmsha, Ltd.: Tokyo, 1997.

(13) Roussel, F.; Knerr, L.; Grathwohl, M.; Schmidt, R. R. Org. Lett. 2000, 2, 3043.

5498 J. Org. Chem., Vol. 69, No. 16, 2004

\section{SCHEME 2. Successful Synthesis of Saponin 1a}
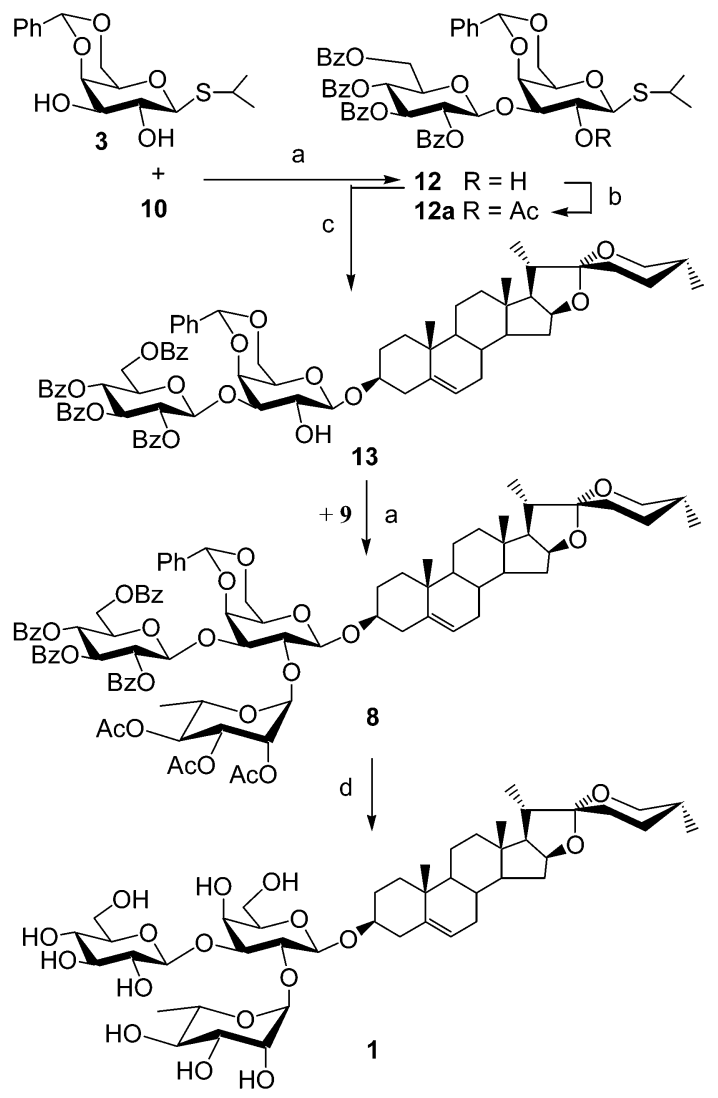

\footnotetext{
a Reagents and conditions: (a) TMSOTf, $\mathrm{CH}_{2} \mathrm{Cl}_{2}, 0{ }^{\circ} \mathrm{C}, 86 \%$ for 12; $84 \%$ for 8. (b) $\mathrm{Ac}_{2} \mathrm{O}$, Pyr. (c) Diosgenin, NIS, TMSOTf, $\mathrm{CH}_{2} \mathrm{Cl}_{2}$, $-42{ }^{\circ} \mathrm{C}, 63 \%$. (d) Aqueous $80 \% \mathrm{AcOH}$, then aqueous $1 \mathrm{~N} \mathrm{NaOH}$, $\mathrm{MeOH} / \mathrm{CH}_{2} \mathrm{Cl}_{2} 2: 1,81 \%$
}

glucosyl imidate 10 in $\mathrm{CH}_{2} \mathrm{Cl}_{2}$ with trimethylsilyl trifluoromethanesulfonate (TMSOTf) promotion was problematic. The crude protected saponin $\mathbf{8}$ was obtained in a low yield ( $27 \%)$. MS analysis showed the presence of 8, but a sufficiently pure sample for NMR analysis could not be obtained. A detailed evaluation of this reaction suggested that the $3-\mathrm{OH}$ of the galactosyl moiety was encircled by the 4,6-benzylidene group and the fully protected rhamnosyl residue, making the $3-\mathrm{OH}$ group sterically inaccessible for glycosylation. To circumvent this problem, fully benzoylated donor $\mathbf{1 0}$ was replaced with a smaller acetylated glucosyl imidate 11; however, this reaction was sluggish, indicating that Scheme 1 was an impractical route to target saponin.

We next turned our attention to an alternative strategy for the efficient synthesis of natural saponin $\mathbf{1}$ utilizing a partially protected disaccharide donor $\mathbf{1 2}$ (Scheme 2). Tothese ends, sugar diol $\mathbf{3}$ was glycosylated with imidate donor 10 in anhydrous $\mathrm{CH}_{2} \mathrm{Cl}_{2}$ at $0{ }^{\circ} \mathrm{C}$ using TMSOTf catalyst, regioselectively affording the $1 \rightarrow 3$-linked disaccharide 12 in $86 \%$ yield. ${ }^{14}$ To confirm its structure, compound $\mathbf{1 2}$ was acetylated with $\mathrm{Ac}_{2} \mathrm{O}$ in pyridine to generate 12a. The ${ }^{1} \mathrm{H}$ NMR spectra of $12 \mathbf{a}$ showed an $\mathrm{H}-2$ signal ( $\delta 5.31 \mathrm{ppm}$ ) shifted downfield from the corresponding $\mathrm{H}-2$ signal of $\mathbf{1 2}$ ( $\delta 3.90$ ppm). Glycosylation of diosgenin with partially protected disaccharide

(14) He, H.; Yang, F.; Du, Y. Carbohydr. Res. 2002, 337, 1673 


\section{SCHEME 3. Retrosynthetic Analysis of Saponin 2}
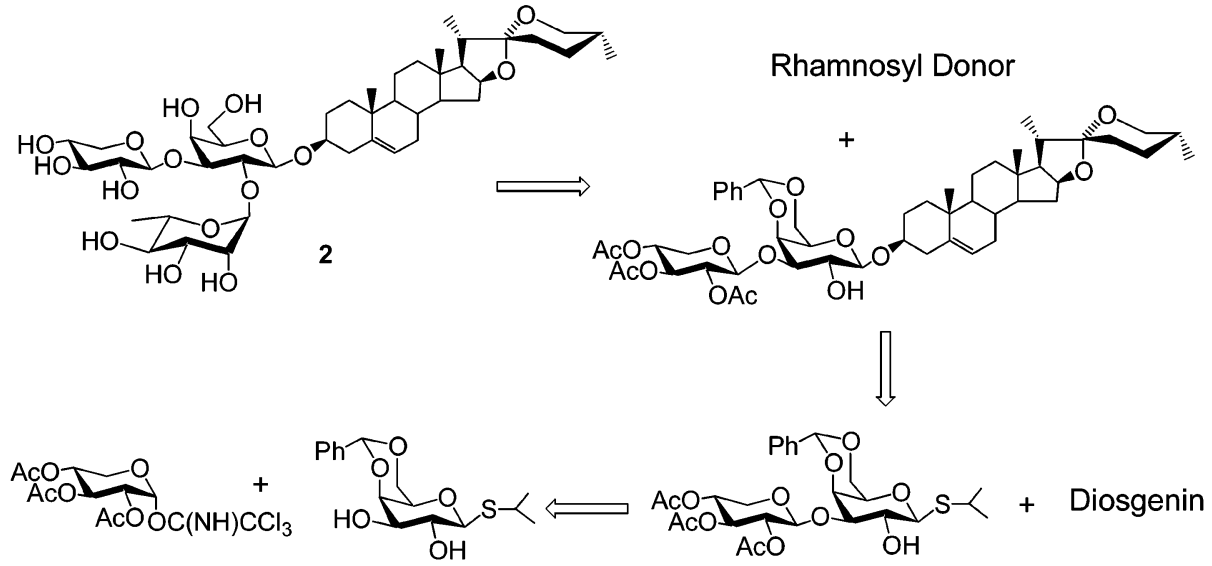

donor 12 in dry $\mathrm{CH}_{2} \mathrm{Cl}_{2}$ at $0{ }^{\circ} \mathrm{C}$, under the promotion of $\mathrm{N}$-iodosuccinimide (NIS) and TMSOTf, afforded $\mathbf{1 3}$ in $63 \%$ yield. Introduction of the rhamnosyl moiety 9 into $\mathbf{1 3}$ under standard glycosylation conditions afforded the protected saponin derivative $\mathbf{8}$. Treatment of $\mathbf{8}$ in aqueous $80 \%$ acetic acid and $1 \mathrm{~N} \mathrm{NaOH}$ gave the natural saponin $\mathbf{1}$ in five steps and a 30\% overall yield.

With the successful completion of the synthesis of saponin $\mathbf{1}$, our attention was turned to the synthesis of natural product $\mathbf{2}$, which we thought could be prepared in a similar way (Scheme 3). Surprisingly, when galactose diol $\mathbf{3}$ was glycosylated with acetylated xylopyranosyl imidate 14 (Scheme 4), the $1 \rightarrow 2$-linked disaccharide 15 was obtained as the major product (54\%), together with the 2,3-dixylosylated trisaccharide (35\%) and recovered starting material 3. To establish the linkage position, 15 was acetylated with acetic anhydride in pyridine to give 16. The ${ }^{1} \mathrm{H}$ NMR spectrum of $\mathbf{1 6}$ showed the $\mathrm{H}-2$ at $\delta$ $4.16 \mathrm{ppm}$ and the $\mathrm{H}-3$ at $\delta 4.93 \mathrm{ppm}$, confirming the presence of a $1 \rightarrow 2$ glycosidic bond in $\mathbf{1 5}$. The desired $1 \rightarrow 3$ linked disaccharide could not be obtained as a major product by changing solvent, catalyst, or reaction temperature. Curious about this regioselectivity, we undertook a detailed investigation of the scope of this reaction (Scheme 4). Glycosylation of galactosyl diol $\mathbf{3}$ with benzoylated xylopyranosyl imidate $\mathbf{1 7}$ afforded isopropyl 2,3,4-tri-O-benzoyl- $\beta$-D-(1 $\rightarrow 2)-4,6$-O-benzylidene-1-thio- $\beta$ D-galactopyranoside $\mathbf{1 8}$ in 65\% yield. The fully assigned ${ }^{1} \mathrm{H}$ NMR spectrum of the acetylated derivative 19 confirmed its $1 \rightarrow 2$ linkage. I nterestingly, the xylosyl residues in 18 and 19 adopt a ${ }^{1} C_{4}$ conformation, instead of the typical ${ }^{4} C_{1}$ form. This conformational assignment was supported by the small coupling constants observed for $19\left(\mathrm{~J}_{1,2}=3.9, \mathrm{~J}_{2,3}=\mathrm{J}_{3,4}=5.7, \mathrm{~J}_{4,5 \mathrm{a}}=4.2, \mathrm{~J}_{4,5 \mathrm{~b}}=3.4 \mathrm{~Hz}\right.$ ). When glucopyranosyl 2,3-diol $\mathbf{2 0}$ was glycosylated with xylosyl donor 14, a $1 \rightarrow 2$-linked disaccharide $\mathbf{2 1}(48 \%)$ was again isolated. In contrast, glucosyl donor $\mathbf{1 0}$ predominantly afforded the $\beta$-( $1 \rightarrow 3$ )-linked disaccharide $\mathbf{2 3}$ (83\%), as supported by ${ }^{1} \mathrm{H}$ NMR spectra analysis of its chloroacetylated derivative $\mathbf{2 4}$. Xylosylation of the diosgenyl galactopyranoside 25 al so afforded the undesired $\beta-(1 \rightarrow 2)$ product 26, confirming that this was an unsuccessful strategy for synthesizing target $\mathbf{2}$. Realizing that regioand stereochemical control is critical in synthesis of natural saponins and inspired by the observation that glucosyl and xylosyl donors show different reactivity in
SCHEME 4. Studies on Regioselective Glycosylationa $^{\text {a }}$

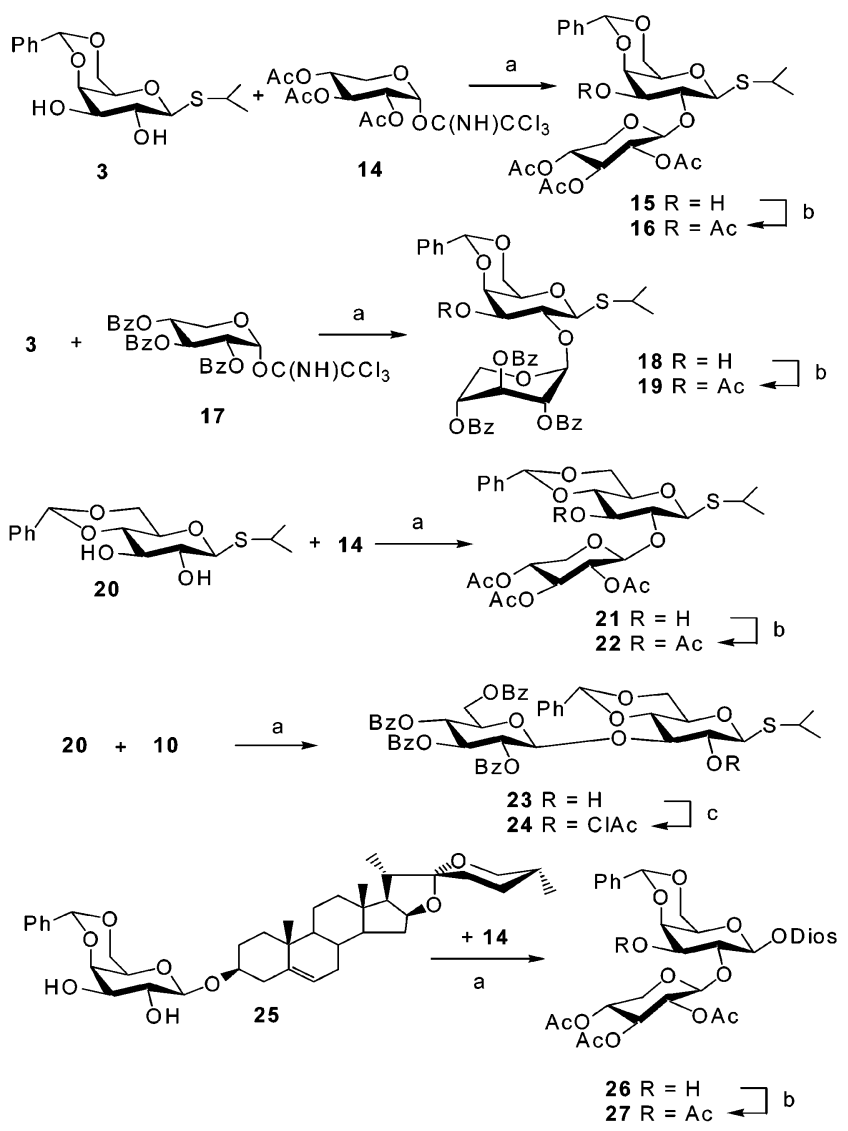

a Reagents and conditions: (a) TMSOTf, $\mathrm{CH}_{2} \mathrm{Cl}_{2}, 0{ }^{\circ} \mathrm{C}, 54 \%$ for 15; $65 \%$ for 18 ; $48 \%$ for $21 ; 83 \%$ for $23 ; 51 \%$ for 26. (b) $\mathrm{Ac}_{2} \mathrm{O}$, Pyr. (c) $\mathrm{ClAcCl}, \mathrm{Pyr}$.

glycosylation (as observed in Scheme 4, $20+\mathbf{1 4}$ and $\mathbf{2 0}$ $+\mathbf{1 0}$ ), we attempted to xylosylate the 3-position of 7, despite our previous observation that incorporation of $\mathbf{1 0}$ into 7 had failed (Scheme 1). Thus, the acetyl-protected xylosyl imidate $\mathbf{1 4}$ was initially used to glycosylate the disaccharide glycosyl acceptor 7. Only trace amounts of product were obtained, and the rapid consumption of $\mathbf{1 4}$ was observed by TLC. In contrast, glycosylation of acceptor $\mathbf{7}$ with benzoylated donor 17, carried out in dry $\mathrm{CH}_{2} \mathrm{Cl}_{2}$ with catalytic TMSOTf, afforded the protected 
SCHEME 5. Total Synthesis of Natural Saponin 2a

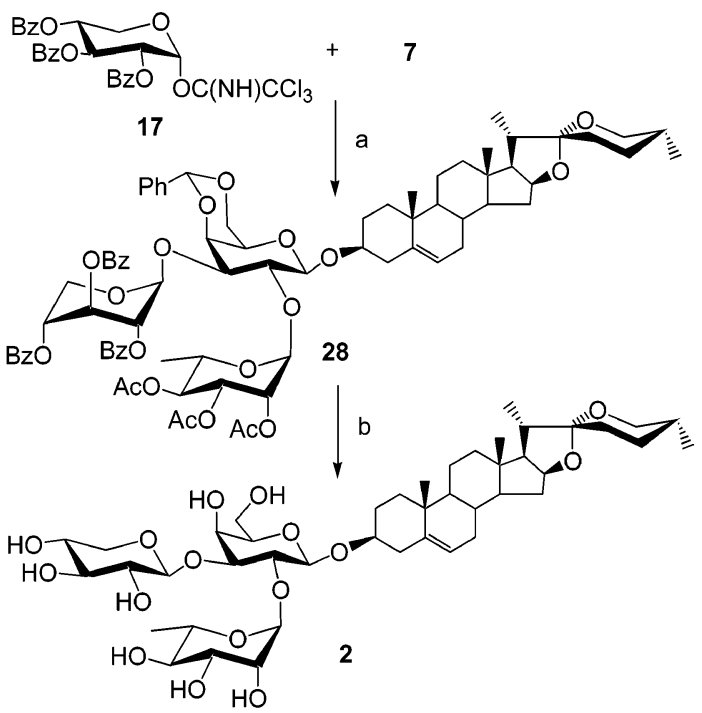

a Reagents and conditions: (a) TMSOTf, $\mathrm{CH}_{2} \mathrm{Cl}_{2}, 0{ }^{\circ} \mathrm{C}, 78 \%$. (b) Aqueous $80 \% \mathrm{AcOH}$, then aqueous $1 \mathrm{~N} \mathrm{NaOH}, \mathrm{MeOH} / \mathrm{CH}_{2} \mathrm{Cl}_{2} 2: 1$, $85 \%$.

saponin derivative $\mathbf{2 8}$ in $\mathbf{7 8 \%}$ isolated yield. The small proton coupling constants of the xylosyl residue $\left(\mathrm{J}_{1,2}<\right.$ $1.0, \mathrm{~J}_{2,3}=\mathrm{J}_{3,4}=3.2, \mathrm{~J}_{4,5 \mathrm{a}}<1.0, \mathrm{~J}_{4,5 \mathrm{~b}}=2.1 \mathrm{~Hz}$ ) of saponin derivative $\mathbf{2 8}$ shows that benzoylated xylose residue takes the ${ }^{1} \mathrm{C}_{4}$ conformation instead of typical ${ }^{4} \mathrm{C}_{1}$ form. The xylosyl C-1 signal appears at $\delta 100.03$ ppm in the ${ }^{13} \mathrm{C}$ NMR spectra, confirming its $\beta$-linkage to the galactosyl residue. Deprotection of $\mathbf{2 8}$ using aqueous $80 \%$ acetic acid, followed by deacylation with $1 \mathrm{~N} \mathrm{NaOH}$ furnished natural saponin $\mathbf{2}$ in six steps from commercially available isopropyl $\beta$-D-1-thiogalactopyranoside (IPTG) and in a $31 \%$ overall yield. A doublet, corresponding to xylosyl $\mathrm{H}-1$, at $\delta 5.05 \mathrm{ppm}(\mathrm{J}=7.5 \mathrm{~Hz})$ in ${ }^{1} \mathrm{H} \mathrm{NMR}$ spectra indicates the expected xylosyl ${ }^{4} \mathrm{C}_{1}$ conformation in natural product $\mathbf{2}$. The cytotoxicity of compounds $\mathbf{1}$ and $\mathbf{2}$ was examined using the procedure of Connolly et al. ${ }^{15}$ Saponin 2 showed good activity $\left(\mathrm{IC}_{50}<6 \mu \mathrm{g} / \mathrm{mL}\right)$ toward human hepatocellular carcinoma BEL-7402 cells. The combinatorial synthesis of analogues of $\mathbf{2}$ is currently under investigation by our group.

In conclusion, an efficient and practical method has been developed for the synthesis of saponins with 2,3branched oligosaccharide moieties. The key to this approach is the use of partially unprotected thioglycoside donors, resulting in significantly simplified protecting group manipulation and oligosaccharide assembly. The results of the present investigation should be of value in the synthesis of 2,3-branched natural steroidal glycosides. ${ }^{16}$ Importantly, the application of this method in combinatorial chemistry may generate an efficient entry into libraries of more complex glycoconjugates. ${ }^{17}$

(15) Connolly, D. T.; Knight, M. B.; Harakas, N. K.; Wittwer, A. J .; Feder, J. Anal. Biochem. 1986, 152, 136.

\section{Experimental Section}

Diosgenyl 3-O-Fluorenylmethoxycarbonyl-4,6-di-O-benzylidene- $\beta$-D-galactopyranoside (5). To a solution of compound 4 (1.1 g, $2.01 \mathrm{mmol}$ ) and diosgenin (833 $\mathrm{mg}, 2.01 \mathrm{mmol})$ in anhydrous $\mathrm{CH}_{2} \mathrm{Cl}_{2}(10 \mathrm{~mL})$ were added NIS $(497 \mathrm{mg}, 2.21$ $\mathrm{mmol}$ ) and a catalytic amount of TMSOTf ( $36 \mu \mathrm{L}, 0.2 \mathrm{mmol}$ ) at $-42{ }^{\circ} \mathrm{C}$ under $\mathrm{N}_{2}$ protection. The mixture was stirred under these conditions for $45 \mathrm{~min}$, at the end of which time TLC indicated that the reaction was complete. The reaction mixture was neutralized with $\mathrm{Et}_{3} \mathrm{~N}$ and concentrated to dryness. The residue was subjected to col umn chromatography on a silica gel column with $5: 1$ petrol eum ether/EtOAc as the eluent to give 5 as a white solid (1.34 g, 75\%); $[\alpha]^{20} \mathrm{D}-34^{\circ}\left(\mathrm{c} 1.3, \mathrm{CHCl}_{3}\right)$. Selected ${ }^{1} \mathrm{H} N M R$ $\left(\mathrm{CDCl}_{3}\right): \delta 0.79(\mathrm{~d}, 6 \mathrm{H}, \mathrm{J}=6.2 \mathrm{~Hz}), 0.89-0.96(\mathrm{~m}, 2 \mathrm{H}), 0.97(\mathrm{~d}$, $3 \mathrm{H}, \mathrm{J}=6.9 \mathrm{~Hz}), 1.03(\mathrm{~s}, 3 \mathrm{H}), 1.04-2.38(\mathrm{~m}, 22 \mathrm{H}), 3.37(\mathrm{t}, 1 \mathrm{H}$, $\mathrm{J}=10.9 \mathrm{~Hz}), 3.46-3.50(\mathrm{~m}, 2 \mathrm{H}), 3.55-3.66(\mathrm{~m}, 1 \mathrm{H}), 4.04-$ $4.09(\mathrm{~m}, 2 \mathrm{H}), 4.27-4.34(\mathrm{~m}, 2 \mathrm{H}), 4.35-4.50(\mathrm{~m}, 5 \mathrm{H}), 4.75$ (dd, $1 \mathrm{H}, \mathrm{J}=10.2,3.7 \mathrm{~Hz}), 5.34(\mathrm{br} \mathrm{d}, 1 \mathrm{H}, \mathrm{J}=5.6 \mathrm{~Hz}), 5.51(\mathrm{~s}, 1 \mathrm{H})$, 7.42-8.11 (13 H, Ph). Anal. Calcd for $\mathrm{C}_{55} \mathrm{H}_{66} \mathrm{O}_{10}$ : C, 74.47; $\mathrm{H}$ 7.50. Found: $C, 74.69 ; \mathrm{H}, 7.41$.

Diosgenyl 2,3,4,6-Tetra-O-benzoyl- $\beta$-D-glucopyranosyl$(1 \rightarrow 3)-4,6$-di-0-benzylidene- $\beta$-D-galactopyranoside (13). To a solution of compound 12 (452 $\mathrm{mg}, 0.50 \mathrm{mmol})$ and diosgenin (207 $\mathrm{mg}, 0.50 \mathrm{mmol})$ in anhydrous dichloromethane $(8 \mathrm{~mL})$ were added NIS (124 mg, $0.55 \mathrm{mmol}$ ) and a catalytic amount of TMSOTf ( $11 \mu \mathrm{L}, 0.06 \mathrm{mmol})$ at $-42{ }^{\circ} \mathrm{C}$ under $\mathrm{N}_{2}$ protection. The reaction mixture was stirred under these conditions for $45 \mathrm{~min}$, at the end of which time TLC indicated the completion of the reaction. The mixture was then neutralized with $\mathrm{Et}_{3} \mathrm{~N}$ and concentrated. The residue was subjected to column chromatography on a silica gel column with 3:1 petroleum ether/EtOAc as the eluent to give 13 as a white solid (391 mg, 63\%); $[\alpha]^{20} \mathrm{D}-24^{\circ}$ (c 1, $\left.\mathrm{CHCl}_{3}\right)$. Selected ${ }^{1} \mathrm{H}$ NMR $\left(\mathrm{CDCl}_{3}\right): \delta 0.79(\mathrm{~d}, 6 \mathrm{H}$, J $=6.3$ $\mathrm{Hz}), 0.97(\mathrm{~d}, 3 \mathrm{H}, \mathrm{J}=6.9 \mathrm{~Hz}), 1.00(\mathrm{~s}, 3 \mathrm{H}), 3.23(\mathrm{br} \mathrm{s}, 1 \mathrm{H}), 3.37$ $(\mathrm{t}, 1 \mathrm{H}, \mathrm{J}=10.9 \mathrm{~Hz}), 3.45-3.57(\mathrm{~m}, 2 \mathrm{H}), 3.74(\mathrm{dd}, 1 \mathrm{H}, \mathrm{J}=9.6$, $3.3 \mathrm{~Hz}), 3.81-3.88(\mathrm{~m}, 2 \mathrm{H}), 4.15-4.22(\mathrm{~m}, 3 \mathrm{H}), 4.33(\mathrm{~d}, 1 \mathrm{H}$, J $=7.6 \mathrm{~Hz}), 4.39(\mathrm{q}, 1 \mathrm{H}, \mathrm{J}=7.5 \mathrm{~Hz}), 4.53(\mathrm{dd}, 1 \mathrm{H}, \mathrm{J}=12.2,5.3$ $\mathrm{Hz}), 4.68(\mathrm{dd}, 1 \mathrm{H}, \mathrm{J}=12.2,3.0 \mathrm{~Hz}), 5.32(\mathrm{~d}, 1 \mathrm{H}$, J $=5.0 \mathrm{~Hz})$, $5.38(\mathrm{~d}, 1 \mathrm{H}, \mathrm{J}=7.9 \mathrm{~Hz}), 5.40(\mathrm{~s}, 1 \mathrm{H}), 5.57(\mathrm{dd}, 1 \mathrm{H}, \mathrm{J}=9.6,7.9$ $\mathrm{Hz}), 5.69(\mathrm{t}, 1 \mathrm{H}, \mathrm{J}=9.6 \mathrm{~Hz}), 5.91(\mathrm{t}, 1 \mathrm{H}, \mathrm{J}=9.6 \mathrm{~Hz}), 7.25-$ $8.05(\mathrm{~m}, 25 \mathrm{H})$. Anal. Calcd for $\mathrm{C}_{74} \mathrm{H}_{82} \mathrm{O}_{17}: \mathrm{C}, 71.48 ; \mathrm{H}, 6.65$. Found: C, 71.69; $\mathrm{H}, 6.48$.

Acknowledgment. This work was supported by National Basic Research Program of China (2003CB415001), NNSF of China (20372081, 30330690), and the NIH (HL62244).

Supporting Information Available: Preparation and physical data for compounds $3-8,12,12 a, 13,1,16,19,24$, $\mathbf{2 5}, \mathbf{2 7}, \mathbf{2 8}$, and $\mathbf{2}$. This material is available free of charge via the Internet at http://pubs.acs.org.

J 00493929

(16) (a) Friedman, M.; Roitman, J . N.; Kozukue, N. J . Agric. Food Chem. 2003, 51, 2964. (b) Putalun, W.; Xuan, L. J .; Tanaka, H.; Shoyama, Y.J . Nat. Prod. 1999, 62, 181. (c) Wanyonyi, A. W.; Chhabra, S. C.; Mkoji, G.; Eilert, U.; Njue, W. M. Phytochemistry 2002, 59, 79. (d) Nakamura, T.; Komori, C.; Lee, Y. Y.; Hashimoto, F.; Yahara, S.; Nohara, T.; Ejima, A. Biol. Pharm. Bull. 1996, 19, 564. (e) Mimaki, Y.; I shibashi, N.; Ori, K.; Sashida, Y. Phytochemi stry 1992, 31, 1753. (f) Dong, M.; Feng, X.; Wang, B.; Wu, L.; I kejima, T. Tetrahedron 2001, 57, 501. (g) Yokosuka, A.; Mimaki, Y.; Sashida, Y. Phytochemistry 2002 $61,73$.

(17) Marcaurelle, L. A.; Seeberger, P. H. Curr. Opin. Chem. Biol. 2002, 6, 289. 